\title{
External Elastic Membrane
}

National Cancer Institute

\section{Source}

National Cancer Institute. External Elastic Membrane. NCI Thesaurus. Code C32555.

A thin layer of fibrous tissue capable of stretching and contracting. It is part of the tunica media of the blood vessels. 